\title{
IS HELICOVERPA ARMIGERA (LEPIDOPTERA: NOCTUIDAE) A KEY PEST IN WESTERN ROMANIAN PAPRIKA PEPPER CROPS?
}

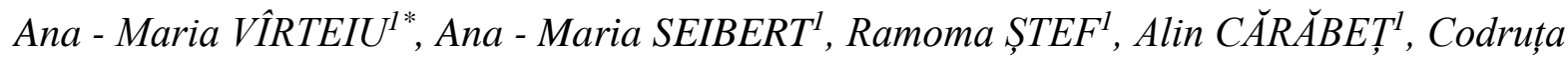 \\ CHIȘ ${ }^{1}$, Ioana GROZEA ${ }^{1}$
}

${ }^{1}$ Department of Biology and Plant Protection, Banat's University of Agricultural Sciences and Veterinary Medicine "King Michael I of Romania" from Timisoara

"Corresponding author:

Banat's University of Agricultural Sciences and Veterinary Medicine "King Michael I of Romania" from Timisoara

119 CaleaAradului, 300645, Timișoara, Timiș

Tel: 0256277009

Fax: 0256200296

E-mail: anamariavarteiu@usab-tm.ro

http://www.doi.org/10.54574/RJPP.14.09

\begin{abstract}
Recent changes in intensive vegetable production systems in Romania, but also throughout Europe, with the frequent and sometimes exclusive use of monoculture for certain groups of vegetables, including the Solanaceae group, have resulted in major changes in entomofauna in these areas. In addition, we are witnessing global climate change that also affects the composition and density of entomofauna in these agro-ecological areas. Under the influence of these two decisive factors, the dynamics of a pest population is oscillating and, therefore, some less known or newly entered species in the research area (invasive species) begin to cause significant damage to crops and especially to their control. 20 years after the first mentions of the attack, this pest causes considerable damage to the pepper crop, in the case of the present study, paprika. From the pepper crop for paprika, in 2020 in Chişlaca locality, Arad County, a number of 11 pest species were collected. The species Helicoverpa armigera was the predominant species, registering the highest number of specimens. The dynamics of larval populations showed an oscillating evolution, depending on climatic conditions, the maximum threshold being reached on the third decade of August.
\end{abstract}

Keywords: Helicoverpa armigera, key pest, western Romanian, paprika pepper crop

\section{INTRODUCTION}

Helicoverpa armigera (Hübner) is one of the most agricultural and economically important pests' species with an extreme polyphagism, that produces extensive outbreaks, and which in its natural occurrence sites has been found on a wide range of host plants, with significant attacks being recorded when it has met favourable climatic conditions for development, or when control strategies have not been properly applied (Forrester et al., 1993; Qin et al., 2003; Specht et al., 2021).

Following the recent publications of several reports on larval population dynamics of $H$. armigera and other arthropods in the western part of Romania (Tomescu \& Negru, 2003; Grozea et al., 2019; Iosub et al., 2021) we acknowledge that there are several factors that cause temporal insect population changes and that those are highly context-specific and taxon-specific.

The knowledge of the pest entomofauna, but also of the useful one, in the intensive production systems is an extremely important desideratum for the agroecological management, because key resources for the management of the pests in the horticulturalvegetable systems are the entomophagous insects (Barbosa et al., 2012). Scientific information on biodiversity presents in a given area on the one hand, and the ecological function and/or eating habits of insects on the other hand, are essential. 
In the Chișlaca area (Arad County) the vegetable production systems can be described as dependent/ very dependent on fertilization and chemical pest control. In this context, we set out to investigate the pest entomofauna of paprika pepper, and also to follow the dynamics of the key pest $H$. armigera.

The results obtained complete the existing data in the literature and thus contribute to the elaboration of the best management plan in preventing and controlling this species, whose expansion on our country territory has been highly accelerated.

\section{MATERIALS AND METHODS}

In the area of Chișlaca locality (Arad County) the main agricultural activity is related to the cereals, corn and forage leguminous crops. Secondary to this, in terms of the arable area is the vegetable activity.

Stupino et al (2014) emphasized that knowledge of the entomofauna present in intensive farming systems is extremely important for an agro-ecological approach, as useful insects are the key source in pest management in vegetable crops, greatly reducing the amount of applied pesticides, but at the same time ensuring proper pollination. One of the most desired objectives of sustainable agriculture systems is the maintenance and management of agrobiodiversity.

Description of the investigated area: The study was carried out in the northern part of

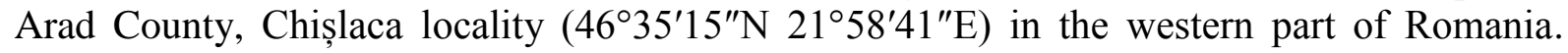
According to Tudoran (1983) and Vlad (2009), the area under study is characterized by the extensive brown soils dominated by loamy-sand to depth, well drained due to the deep groundwater, with a high content of humus and nutrients, neutral reaction, weakly alkaline; with an annual mean temperature of $10.5^{\circ} \mathrm{C}$ and an average annual rainfall of $700 \mathrm{~mm}$. The climate, through all its basic characteristics, appears as favourable for the forest and pasture vegetation as for the main agricultural crops.

The paprika pepper variety Mihnea (figure 1), a widely used cultivar with high growth and yield potential, was planted on May 8, 2020, using 4500 plants, with a $25 \mathrm{~cm}$ planting distance, following the recommended agronomical practices: the preparation of the land started in autumn, after deep ploughing, followed by the disking soil and the administration of fertilizers: $280 \mathrm{~kg}$ of manure, $42 \mathrm{~kg}$ of superphosphate and $14 \mathrm{~kg}$ of potassium sulphate; in the spring, after a thorough preparation of the germination layer with the help of the cultivator, 28 $\mathrm{kg}$ of ammonium nitrate were applied; at 14 days after planting, the ATONIK foliar biostimulator $\left(0.06 \mathrm{l} / 1000 \mathrm{~m}^{2}\right)$ was applied. During the vegetation period, 2 foliar fertilizations were performed: the first fertilization at the flowering stage of the basal flowers with Algaren (100 ml/ 1001 water $)+$ Calfomyth $(150 \mathrm{ml} / 1001$ water $)$; and the second at the fruit growing stages with Foliacon 22 (350 ml/ 1001 water) + DRIN (100 ml/ 1001 water).
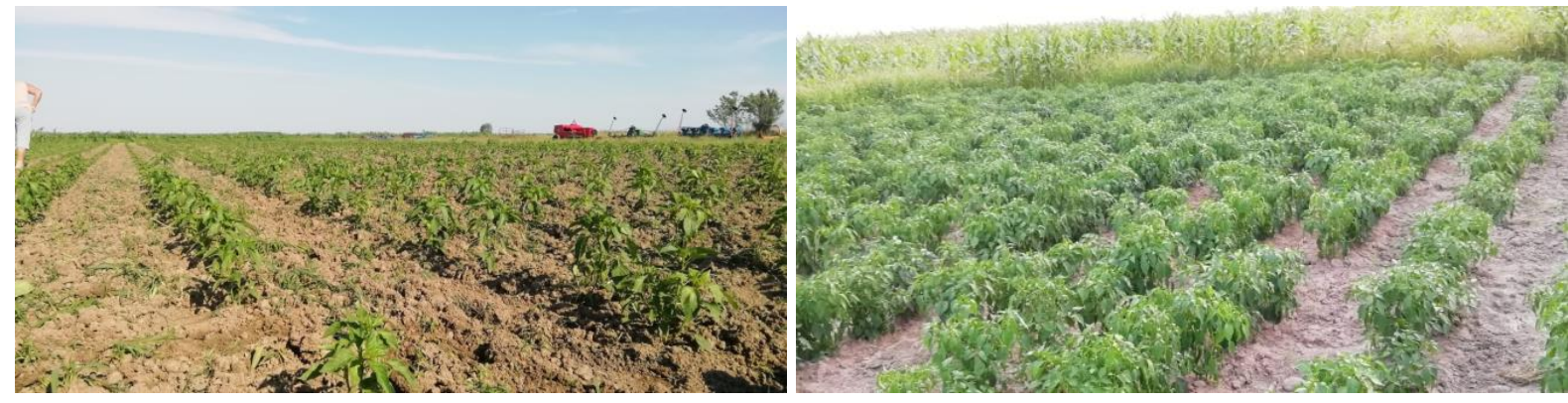

Figure 1. Aspects from the experimental fields, Chișlaca, Arad County 
The total area of the experimental field was $1400 \mathrm{~m}^{2}$ (figure 1, with a plot size of $3 \times 25$ $\mathrm{m}$ and a path of $1,0 \mathrm{~m}$ width was maintained around each plot. Trials were conducted in randomized block design in 3 replications. The harvest was carried out on 02.10.2020, obtaining an amount of $100 \mathrm{~kg}$ of paprika pepper/ $1400 \mathrm{~m}^{2}$.

Survey on insects' biodiversity: Surveys were carried out between the end of May 2020 and the beginning of October 2020, with a collecting periodicity every 7-10 days.

The first stage of biological material collecting consisted in direct visual control of the plants (figure 2) and the second stage (from the moment of flowering until harvest) consisted in collecting with the help of entomological umbrella - using beating tray methods (Dzokou et al., 2021; Vîrteiu et al., 2015). The sample standard per harvest unit was 5 beats per $\mathrm{m}^{2}$ performed on an area of $20 \mathrm{~m}$. The number of pests was reported per $\mathrm{m}^{2}$. Harvesting took place on sunny days, without humidity and precipitation, in the morning, until 11 o'clock.

Observation on Helicoverpa armigera larval population dynamics: For monitoring the $H$. armigera on paprika pepper crop, the observations began in the last decade of July when the plants were in full blooming stages and continued till maturity of pepper fruits. The $2^{\text {nd }}$ instar larval population was recorded with the help of metrical frame $(1 \times 1 \mathrm{~m})$ (Goodall, 1952; Pawan et al., 2017). A total of 55 samples were collected at 7 days interval during the active vegetation period (Michereff-Filho et al., 2021). Insects larval populations (no of individuals $/ 1 \mathrm{~m}^{2}$ ) were recorded on 5 randomly selected observation points per each sample dates (figure 3). At each observation point, the metrical frame was randomly placed and the plants inside were studied (Kennedy \& Addison, 1987). On each plant pest identification was carried out and percentage of damage fruits per plant was estimated (Pribetić et al., 2007).

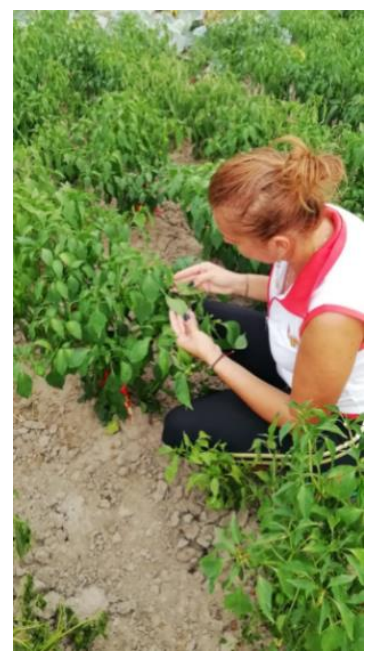

Figure 2. Direct observation methods

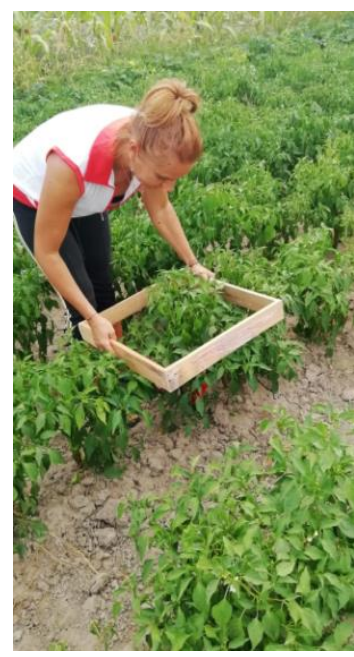

Figure 3. Metrical frame methods

Meteorological data: Monthly mean temperatures, atmospheric humidity and precipitation of the study period were obtained from Ineu hydrological point and by interpolation from the office of the National Institute of Meteorology - Arad Meteorological Station.

Data analysis: Statistical calculations were performed with IBM-SPSS-Statistics. Descriptive statistical elements calculated were: means, standard deviations, minimum and maximum values for the studied variables. Linear, cubic, quadratic, and logarithmic correlations were determined. 


\section{RESULTS AND DISCUSSION}

From 35 insects species mentioned as harmful to paprika pepper crops and occur frequently throughout our country, 11 species have been identified in the experimental field and, of these only 7 species can be considered of economic importance (table 1). The vast majority of these species attack the leaves and fruits, but some can also be vectors of diseases, so the losses can be considerable. Obviously, the species that cause damage to fruit are the ones that interest vegetable farmers, in particular, as they depreciate not only quantitatively, but especially qualitatively.

Table 1.Insect species and number of specimens collected from paprika pepper crops in Chișlaca, Arad County

\begin{tabular}{|c|c|c|}
\hline Family & Species & $\begin{array}{l}\text { Total no. of } \\
\text { specimens }\end{array}$ \\
\hline Forficulidae & Forficula auricularia Linnaeus, 1758 & 5 \\
\hline Thripidae & Thrips tabaci Lindeman, 1889 & 63 \\
\hline Miridae & Lygus lineolaris Palisot de Beauvois, 1818 & 12 \\
\hline Pentatomidae & Nezara viridula Linnaeus, 1758 & 36 \\
\hline Aleyrodidae & Trialeurodes vaporariorum Westwood, 1856 & 56 \\
\hline \multirow{3}{*}{ Aphididae } & Aphis grossypii Glover, 1877 & $15 \mathrm{col}$ \\
\hline & Macrosiphum euphorbiae Thomas, 1878 & $23 \mathrm{col}$ \\
\hline & Myzus persicae Sulzer, 1877 & $19 \mathrm{col}$ \\
\hline \multirow{4}{*}{ Curculionidae } & Autographa gamma Linnaeus, 1758 & 8 \\
\hline & Helicoverpa armigera Hübner, 1809 & 96 \\
\hline & Spodoptera littoralis Boisduval, 183 & 5 \\
\hline & & 338 \\
\hline
\end{tabular}

There are three critical periods for paprika pepper crops, in which insect damage is essential. The first critical period - until mid-June, when the aphid and greenhouse whitefly attack, establishing numerous colonies in pepper crops. A second critical period - mid-July, the $2^{\text {nd }}$ generation of $H$. armigera, Spodoptera littoralis and Autographa gamma populations appear. A third critical period - the end of August - the beginning of September, Nezara viridula and $H$. armigera larvae reached the maximum level of attack in the absence of a control program.

From all the species reported in this paper, $46.45 \%$ are fruit harmful species, $33.43 \%$ leaves damaging species and only $18.64 \%$ attack the inflorescences, and $1.48 \%$ are beneficial species ( $F$. auricularia), which can act as alternative prey or as predators.

From data presented in table 1, visible differences between species are highlighted. Among the most numerous species were: H. armigera $(28.40 \%), N$. viridula $(10.65 \%)$ and Lygus lineolaris $(3.55 \%)$ - attacked the fruits; as well as pests that attacked the leaves: Trialeurodes vaporariorum (16.57\%), aphids (Macrosiphum euphorbiae, Aphis grossypii and Myzus persicae - 16.86\%) and Thrips tabaci (18.64\%). Over all pest species, Helicoverpa armigera was the most abundant with 96 specimens, followed by Thrips tabaci with 63 specimens present on all samples. 
Similar to those highlighted by us, Hashmi (1996) reported the Spodoptera littoralis larvae feeding on the lower surface of pepper leaves and as final consequence - plant death. According to Hoddle (2012) T. tabaci was the second major pest of pepper varieties, but it was also found on a large number of other host plants, due to increased polyphagism. Severe attacks of $T$. tabaci can result in total defoliation and potential crop loss (Ananthakrishnan, 1984). According to Grozea et al., $(2012,2015,2016)$ researches, the southern green stink bug, $N$. viridula is a polyphagous species, newly invasive for our country, which feeds on a wide range of mono - and dicotyledonous plants, preferring Solanaceae family plants, which through attacks on fruiting periods, leads to qualitative depreciation of crops.

Helicoverpa armigera (Lepidoptera: Noctuidae) - key pests for paprika pepper crops As we previously have pointed out, the species with the highest number of specimens and which causes at the same times the most significant damages, both in terms of quantity and quality, is $H$. armigera. The species that is a major pest of cotton in its area of origin is became of great interest to farmers, due to its massive presence in western Romania, mainly because it finds common alternative host plant such as: corn, sunflower, peppers, tomatoes, tobacco crops; this can be explained by the adaptability of the species to various food habits, as well as to the constantly changing climatic conditions.

This pest is known as a polyphagous, multivoltine and cosmopolitan pest species at the same time, reproducing on 182 host plant species belonging to 47 botanical families (Pawar, 1998), being at the same time the most important limiting factor for successful pepper crops, due to its high reproduction rates, very high genetic diversity and ability to resist, metabolize and avoid toxic chemicals. During its entire development period a single larvae consumes up to 20 inflorescences (Taggar \& Singh, 2012).

Following $H$. armigera species, in 2020 , we noticed that in the period between the second weeks of May - the first week of June, after the mating flights, the females laid theirs eggs in small groups on pepper vegetative organs, especially on the leaves located in the immediate vicinity of the inflorescences.

The research carried out by Crista and Pălăgeșiu (2007) showed that in the western part of Romania, for maize plants, females and first instars larvae prefer silk, after which they enter into the apical cobs.

In the case of paprika plants, in our study, immediately after hatching the first instars larvae fed on flowers, afterwards they migrated into the newly formed fruits, which they partially destroyed at first, and then they were completely depreciated. Most of the time, immediately after the hatching, one larva per inflorescence was noticed, and later, due to the migration phenomenon, 5 larvae/ inflorescence were found.

In another sampling period 5 larvae on a single plant were observed, of which 2 newly hatched larvae on the inflorescences, two $2^{\text {nd }}$ instar larvae inside the fruit and a mature larva on the leaves at the base of the flowers. Most often, after a period of intense feeding, the mature larvae descend into the soil for pupation (Liu et al., 2004; Baikar \& Naik, 2016; Kumar et al., 2017).

Our observations showed that in some cases, mature larvae never descend into the soil, but pupate inside the attacked pepper fruits. From data analysis, it can be highlighted that on a $1 \mathrm{~m}^{2}$ were recorded attacks ranging from 3 to 15 plants, and the number of larvae ranged from 2 to 25 sampled specimens (table 2 ).

Table 2. Helicoverpa armigera - larvae sample incidence in paprika pepper crops, Chișlaca, Arad County

\begin{tabular}{|l|l|l|l|l|l|}
\hline & $\begin{array}{l}\text { Average } \\
\text { Helicoverpa } \\
\text { larvae /day }\end{array}$ & Infested plants & $\begin{array}{l}\text { Air temperature } \\
\left({ }^{\circ} \mathrm{C}\right)\end{array}$ & $\begin{array}{l}\text { Atmospheric } \\
\text { humidity }(\%)\end{array}$ & $\begin{array}{l}\text { Precipitations } \\
(\mathrm{mm})\end{array}$ \\
\hline
\end{tabular}


ISSN 2248 - 129X; ISSN-L 2248 - 129X

\begin{tabular}{|l|l|r|r|r|r|r|}
\hline & Valid & 10 & 10 & 10 & 10 & 10 \\
\cline { 2 - 7 } & Missing & 0 & 0 & 0 & 0 & 0 \\
\hline \multirow{2}{*}{ Mean } & 16.550 & 11.900 & 21.080 & 67.700 & 1.3000 \\
\hline \multirow{2}{*}{ Median } & 18.500 & 13.500 & 21.200 & 65.000 & .0000 \\
\hline \multirow{2}{*}{ td. Deviation } & 0 & 0 & 0 & 0 & 2.26323 \\
\hline Minimum & 6.3265 & 3.7252 & 3.7195 & 11.700 & .00 \\
\hline Maximum & 2.00 & 9 & 3.00 & 13.30 & 56.00 & 7.00 \\
\hline
\end{tabular}

From figure 4 it can be concluded that during fruiting period, the larval population of $H$. armigera ranges from 1.00 to 4.5 larvae/ plant. The growth model significantly fitted the effect of average $H$. armigera larvae/day $(\mathrm{F}=22.559, P=0.001446)$.

$$
\mathrm{y}=\exp (1.302199535547314+0.06622087614395751 * \mathrm{x})
$$

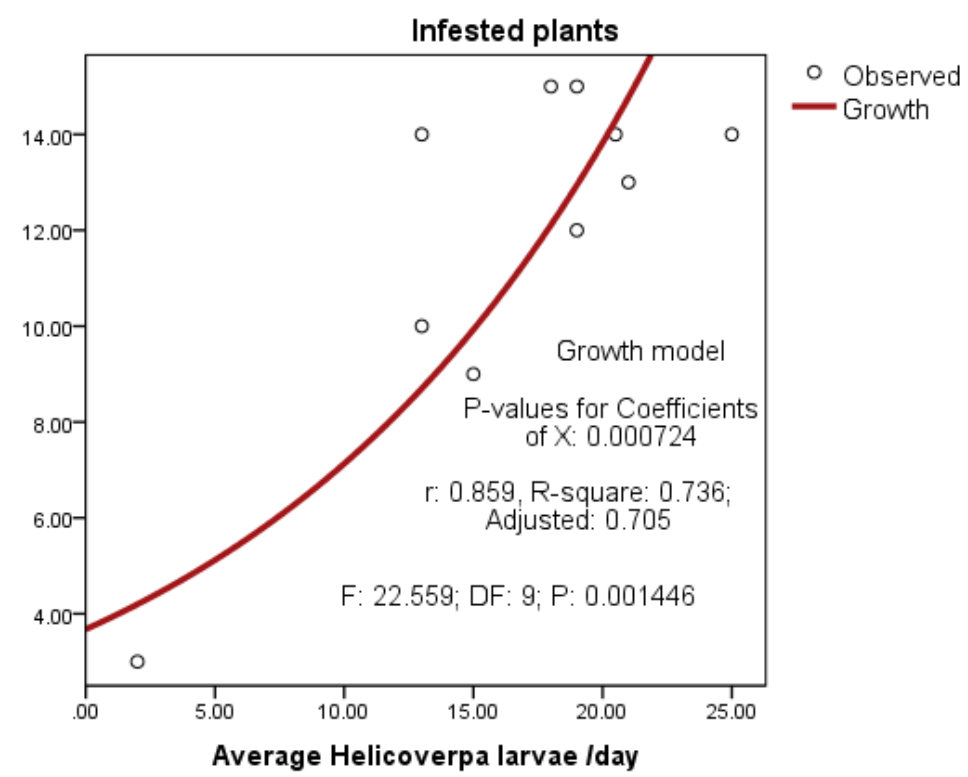

Figure 4. The correlation between the average number of larvae and the number of attacked plants

The larval population was found throughout all active growth stages of paprika pepper, being lower in the first stages (inflorescence stage) and higher in various phases of fruit development. The higher larval population densities was recorded in the $11^{\text {th }}$ week after transplanting seedlings in the field $\left(25 \mathrm{larvae} / \mathrm{m}^{2}\right)$ in the third week of July, and the lowest larval density was recorded in the $22^{\text {nd }}$ standard week $\left(2 \mathrm{larvae} / \mathrm{m}^{2}\right)$ in the first ten days of October. Laval population is gradually decreasing from the $12^{\text {th }}$ standard week (August 06) until harvest. The basic climate parameters, i.e. air temperature and atmospheric humidity, influence the larval population both directly and indirectly. The direct influence can be observed through limiting and stimulating the activity of larvae; and indirect influence includes a climate impact on environment where these larvae appear, such as impact on paprika pepper plant formations. The variations of climatic conditions, such as temperature fluctuations, but especially to fluctuations in relative air humidity have the greatest importance in larval population dynamics.

Nevertheless, our results showed values lower than those reported by Upadhyay et al. (1989), Verma et al. (1994) and Yadav \& Jat (2009) but in the same times showed that the Helicoverpa armigera larvae sample incidence was recorded from July until October. Also, 
following figure 5 , there were significant correlations between the population size and weather factors air temperature $(\mathrm{T})$. The correlation was positive with $\mathrm{T}(\mathrm{r}=0.944, P=$ $0.00004)$ and the linear regression coefficients were highly significant, $(b=0.1 .605$, for $\mathrm{T}$, and $P<0.001)$.

$$
\mathrm{Y}=1.605496482379775 * \mathrm{x}+-17.29386584856565, \mathrm{R}^{2}=0.891
$$

The logarithmic model significantly fitted the effect of $\mathrm{T}(\mathrm{F}=75.535, P=0.00024)$ and the coefficient of $\log \mathrm{X}$ was significant $(P=0.0000986)$.

$$
\begin{aligned}
& \mathrm{Y}=-76.6702+30.7423 * \log (\mathrm{x}) \\
& \mathrm{R}^{2}=0.904
\end{aligned}
$$

It can observe from figure 6 that there were significant correlations between the population size and weather factors atmospheric humidity (\%). The correlation was positive with atmospheric humidity $(\%)(\mathrm{r}=0.853, P=0.11)$ and the cubic regression coefficients were highly significant.

$$
\mathrm{Y}=-61.58492470379807+1.796176710984025 * \mathrm{x}+0 * \mathrm{x}^{2}+-0.0001291314073446404 * \mathrm{x}^{3}
$$

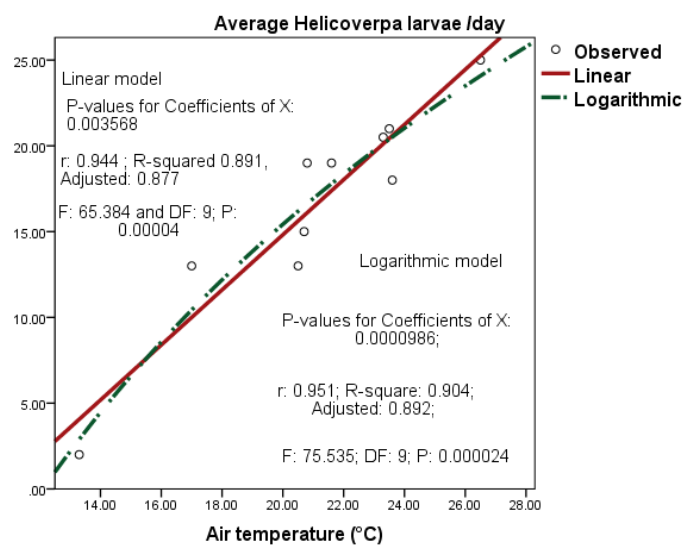

Figure 5. Correlation between air temperature and average number of $H$. armigera larvae

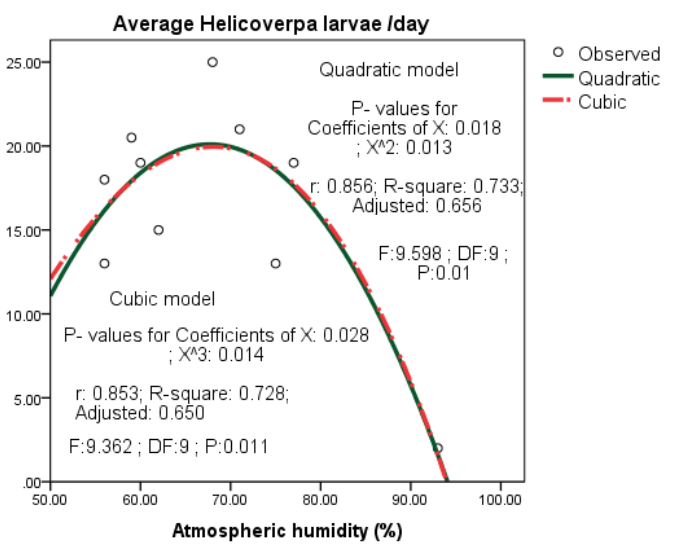

Figure 6. Correlation between atmospheric humidity and average number of $H$. armigera larvae

The polynomial quadratic model significantly fitted the effect of atmospheric humidity $(\%)$. $(\mathrm{F}=9.598, P=0.010)$ and the coefficient of $\mathrm{X}^{\wedge} 2$ was significant $(P=0.013)$.

$\mathrm{Y}=-112.1540072286963+3.90797151082829 * \mathrm{x}+-0.02886766473055963 * \mathrm{x}^{2}$

The results are in agreement with those of Krishna et al. (2007) who reported a positive correlation between larval population and air temperature.

It has been demonstrated once again, that climatic factors directly affect the survival and abundance of pest species (Cammell \& Knight, 1992; Grozea et al., 2009); therefore in the experimental field from Chişlaca (Arad) the larval populations of $H$. armigera registered significant increases in the hot and canicular periods.

Our research suggests that the dynamics of $H$. armigera larval population appear to be more influenced by climatic conditions than by available food resources. Among the climatic factors, temperature plays a key role in the survival and development of the species. The potential effects of temperature on $H$. armigera larval populations are offset by relative air humidity and lack of precipitation, which have also, a positive effect on them. Studying these species dynamics and also of other Noctuidae species, it was observed that an increase in temperature led to an increase in the studied population (Tingle \& Mitchell, 1977; Simmons, 1993). 
We can conclude by saying that a thorough knowledge of pest populations dynamics, in this case of $H$. armigera larvae represents a fundamental element for integrated control strategies implementation in Western Romania climatic conditions, both for pepper and neighbouring crops, such as tomatoes.

\section{CONCLUSIONS}

As an immediate consequence of global warming, we are witnessing, that from one year to the next, the average temperatures above normal and the lack of rainfall during the active period of plant development in western Romania, will lead to increases in population levels above there are at the moment. Therefore, it is necessary to get acquainted with this insect and to identify the most appropriate control methods, so that the quantity, but also the quality, of the crop does not suffer.

\section{REFERENCES}

BAIKAR, A. A., NAIK, K. V. (2016). Efficacy of insecticides against fruit borer, Helicoverpa armigera (Hubner) infesting chilli under laboratory conditions. Plant Archives, 16, 2, 890-892.

BARBOSA, P., LETOURNEAU, DK., AGRAWAL, AA. (2012). Insect outbreaks revisited. WileyBlackwell, Chichester, p. 480.

CAMMELL, M., KNIGHT, J. (1992). Effects of climatic change on the population dynamics of crop pests. Advances in Ecological Research, 22, 117-162.

DZOKOU, V. J., LONTCHI, F. N., YAOUBA, A., BITOM OYONO, L. D., TAMESSE, J. L. (2021). Entomofauna of sweet pepper (Capsicum annuum 1.) in Menoua division, Western Cameroon, Acta Entomology and Zoology, 2, 1, 05-11.

FORRESTER, NW., CAHILL, M., BIRD, L.J.D., LAYLAND, J.K. (1993). Management of pyrethroid and endosulfan resistance in Helicoverpa armigera (Lepidoptera: Noctuidae) in Australia. Bulletin of Entomological Research. Supplement Series, 1, 1-132.

GOODALL, D.W. (1952). Some considerations in the use of point quadrates for the analysis of vegetation. Australian Journal of Scientific Research (Series B: Biological Sciences), 5, 1, 1-41.

GROZEA, I., CĂRĂBEŢ, A.F., STEF, R., VÎRTEIU, AM. (2009). The presence of Diabrotica virgifera virgifera adults at different altitudes, 44th Croatian and 4th International Symposium on Agriculture, Proceedings of Conference, Opatija, Croatia, 513-517.

GROZEA, I., ŞTEF, R., VIRTEIU, A.M., CĂRĂBET, A., MOLNAR, L. (2012). Southern green stink bugs (Nezara viridula L.) a new pest of tomato crops in western Romania. Research Journal of Agricultural Science, 44, 2, 24 - 27.

GROZEA, I., VIRTEIU, A.M., ŞTEF, R., CĂRĂBET, A., MOLNAR, L., FLORIAN, T., VLAD, M. (2015). Trophic evolution of southern green stink bugs (Nezara viridula L.) in Western part of Romania, Bulletin UASVM Horticulture, 72, 2, 371-375, Doi:10.15835/buasvmen-hort:11391.

GROZEA, I., VIRTEIU, A. M., STEF, R., CABARET, A., MOLNAR, L., MARCU, V., DRAGA, D. (2016). The spread of Nezara viridula (Hemiptera:Pentatomidae) species from its first occurrence in Romania. Bulletin UASVM Horticulture, 73, 237- 239, Doi: 10.15835/buasvmen-hort:12128.

GROZEA, I., HORGOS, H., STEF, R., CARABET, A., VIRTEIU, A. M, BUTNARIU, M., MOLNAR, L. (2019). Assessment of population density of insect species called "species problem", in lots with different maize hybrids. Research Journal of Agricultural Science, 55, 1, 132-137.

HASHMI A, A. (1996). Insect pest and disease management. In: Horticulture. Managing Editor M. N. Malik. National Book Foundation, Islamabad, 354-399.

HODDLE, M.S., MOUND, L.A., PARIS, D.L. (2012). Thrips of California 2012. CBIT Publishing, Queensland.

IOSOB, G.-A., CRISTEA, T. O., CĂLIN, M., PRISECARU, M., AVASILOAIEI, D.-I., BUTE, A. (2021). Pests of the solanaceous vegetables: An overview of biological control. Scientific Papers. Series B, Horticulture, 65, 1, $465-476$. 
KENNEDY, K.A., ADDISON, P.A. (1987). Some considerations for the use of visual estimates of plant cover in biomonitoring. Journal of Ecology, 75, 1,151-157.

KRISHNA, K., KANAUJIA, K.R., KANAUJIA, S. (2007). Role of plant density and abiotic factors on population dynamics of Helicoverpa armigera (Hubner) in chick pea. Annals of Plant Protection Sciences, 15, 2, 303-306.

KUMAR, S., SINGH, G., KUMAR, A. (2017). Evaluation of some novel insecticides against Helicoverpa armigera (Hubner) in black gram (Vigna mungo). Journal of Entomology and Zoology Studies 5, 3, 183 - 185.

LIU, Z,. LI, D., GONG, P., WU, K. (2004). Life table studies of the cotton bollworm, Helicoverpa armigera (Hübner) (Lepidoptera: Noctuidae) on different host plants. Environmental Entomology, 33, 1570-1576, Doi:10.1603/0046-225X-33.6.1570.

MICHEREFF-FILHO, M., NORONHA FONSECA, M. E., SILVA BOITEUX, L., BRAZ TORRES, J., AYRES DE SOUZA SILVA, K. F., SPECHT, A. (2021). Helicoverpa armigera Harm 1 haplotype predominates in the Heliothinae (Lepidoptera: Noctuidae) complex infesting tomato crops in Brazil, Neotropical Entomology, 50, 258-268, Doi: 10.1007/s13744-020-00845-z.

PAWAN K OJHA, RENUKA KUMARI AND RAM S CHAUDHARY (2017). Impact of abiotic and biotic factors on population dynamics of Helicoverpa armigera Hubner (Noctuidae: Lepidoptera) in chickpea, Journal of Entomology and Zoology Studies, 5, 1, 636-642.

PAWAR, VM. (1998). Microbial control of Helicoverpa armigera sp. on pulses crops In: IPM System in Agriculture (Upadhyaya R.K., Mukarji K.G. and Rajak RL Eds.) New Delhi, India, Aditya books Private Ltd, 55-78.

PRIBETIĆ, Đ., BAN, D., ILAK PERŠURIĆ, A. S., OPLANIĆ, M., ŽNIDARČIĆ, D. (2007). Nontypical pests on vegetables in Istria, 8th Slovenian Conference on Plant Protection (8. slovensko posvetovanje o varstvu rastlin), Radenci (Slovenia), 335-341.

QIN, S.L., ZHAI, B.P., ZHANG, X.X., ZHAO, Z.G., JIANG, Y.Y., QU, X.F. (2003). Using advance ENSO indices to forecast outbreaks of Helicoverpa armigera. Acta Ecologica Sinica, 23, 9, 16951711.

SIMMONS, A.M. (1993). Effects of constant and fluctuating temperatures and humidities on the survival of Spodoptera frugiperda pupae (Lepidoptera: Noctuidae). Florida Èntomologist, 76, 333-340.

SPECHT, A., SOSA-GÓMEZ, D.R., RIO, S D.A.M. et al. (2021). Helicoverpa armigera (Hübner) (Lepidoptera: Noctuidae) in Brazil: the big outbreak monitored by light traps. Neotropical Entomology, 50, 53-67, Doi: 10.1007/s13744-020-00836-0.

STUPINO, S., IERMANÓ, M.J., GARGOLOFF, N.A., BONICATTO, M.M. (2014). La biodiversidad en los agroecosistemas. Agroecologia: bases teoricas para el diseno y manejo de agroecosistemas sustenables. Coleccion libros de catedra (ed. Sarandon S.J. \& Flores, C.C.), 131 158. Ed. UNLP, La Plata.

TAGGAR, GK., SINGH, R. (2012). Integrated management of insect pests of rabi pulses. In: Arora R, Singh B and Dhawan AK (ed.) Theory and practice of integrated pest management. Scientific Publishers, India; 454-72.

TOMESCU, A., NEGRU, G. (2003). An overview on fungal diseases and pests on the field tomato crops in Romania. Acta Horticulturae, 613, 259-266, Doi: 10.17660/ActaHortic.2003.613.41.

TINGLE, F.C., MITCHELL, E.R. (1977). Seasonal Populations of Armyworms and Loopers at Hastings, Florida. Florida Èntomologist, 60, 115-122.

TUDORAN, P. (1983). Tara Zarandului - studiu geoecologic, Edit. Academiei Republicii Socialiste România, Bucureşti.

UPADHYAY, D.R., VYAS, H.N., SHERASIYA, R.A. (1989). Influence of weather parameters on larval population of Heliothis armigera (Hub.) on groundnut. Indian Journal of Plant Protection, $17,1,85-87$.

VERMA, K.S., KAKAR, K.L., VERMA, A.K. (1994). Incidence, biology and population fluctuations of Heliothis armigera (Hb.) in mid hill region of Himachal Pradesh. Pest Management and Ecomic Zoology, 2, 1, 41-44 
VIRTEIU, A.-M., GROZEA, I., STEF, R., VLAD, M., DOBRIN, I. (2015). Faunistic study of ladybirds (Coleoptera: Coccinellidae) in the Banat region, Romania. Bulletin USAMV series Agriculture, 72, 2, 576-581, Doi: 10.15835/buasvmen- agr: 11489.

VLAD, H. (2009). Cercetări privind solurile şi posibilităţile de restaurare a fertilităţii lor în judeţul Arad, teza de doctorat USAMVB Timisoara.

YADAV, S.R., JAT, B.L. (2009). Season incidence of Helicoverpa armigera (Hub.) on chickpea. Journal of Insect Science, 22, 3, 325-328. 